\title{
Loyalty as Affecting Mediator of Service Quality And Customer Satisfaction Towards Competitive Advantage
}

\author{
Mohammad Hamim Sultoni \\ Universitas Negeri Malang \\ Email: mohammad.hamim.2004139@students.um.ac.id \\ Sudarmiatin \\ Universitas Negeri Malang \\ Email: sudarmiatin.fe@um.ac.id
}

\begin{abstract}
When preparing an effective marketing strategy, a bank must consider its competitors as well as its customers. Establishing a mutual relationship with customers requires a better means of satisfying customer needs than the competitors. Micro, Small, and Medium-sized Enterprises (MSMEs) should always analyze their competitors and develop marketing strategies that effectively give the company a good position compared to the competitors and provide a competitive advantage as strong as possible. This research was conducted using a quantitative method. The design referred to causal relationship research. The data were then analyzed using the path analysis. Findings showed that customer satisfaction, service quality, and customer loyalty affected the competitive advantage of Sentra Batik Pamekasan. The effect of customer loyalty on the competitive advantage could be viewed from the number of Sentra Batik Pamekasan's customers who decided not to move to other financial institutions (banks). When the company could give better service quality, the customer loyalty and the competitive advantage among financial institutions would get higher.
\end{abstract}

Keywords: Customer loyalty, Customer satisfaction, Service quality, Competitive advantage

\begin{abstract}
Abstrak
Dalam mempersiapkan strategi pemasaran yang efektif, pihak perbankan harus mempertimbangkan pesaingnya dan juga konsumennya. Membangun hubungan antara konsumen yang menguntungkan, memerlukan alat pemuasan kebutuhan konsumen sebagai sasaran yang lebih baik daripada pesaingnya. UMKM harus senantiasa menganalisis pesaing dan mengembangkan strategi pemasaran kompetitif yang secara efektif memposisikan UMKM dalam menghadapi pesaing dan memberikan keunggulan kompetitif sekuat mungkin. Penelitian ini menggunakan metode kuantitatif, jenis penelitian termasuk kategori hubungan kausal sedangkan analisis dalam penelitian ini menggunakan analisis jalur (path analysis). Hasil penelitian menunjukkan bahwa kepuasan konsumen, kualitas layanan, dan loyalitas konsumen mempengaruhi keunggulan bersaing di Sentra Batik Pamekasasan. Dampak dari loyalitas konsumen terhadap keunggulan bersaing dapat dilihat dari seberapa banyak konsumen Sentra Batik Pamekasasan yang tidak pindah ke lembaga keuangan lain. Semakin bagus kualitas layanan maka semakin tinggi tingkat loyalitas konsumen dan keunggulan bersaing antar lembaga keuangan juga akan semakin tinggi.
\end{abstract}

Kata Kunci : Loyalitas konsumen, kepuasan konsumen, kualitas layanan, keunggulan bersaing

\section{Introduction}

All companies have a strategy. However, the companies usually do not realize that their plans and activities constitute one strategy to compete. Forms of the system can vary from industry to industry, from company to company, and from situation to situation. Thus, every company might have a different strategy from its competitors.

In the recent decade, stiff competition undeniably occurs in the batik industry. Hence, corporation behavior towards customers should always be taken into account. The competition occurs in many batik and in the efforts to find customers and retain the existing ones. Thus, the perceived 
performance of the company's product is highly required. Perceived performance is based on the customer's knowledge, belief, and evaluation of brand, product performance, image, and services. Once the customers perceive those aspects as satisfactory, customer loyalty will be formed, which is indicated by the repeated use of the product for the long term.

Service activities refer to activities expected by the Micro, Small, and Medium-sized Enterprises (MSMEs) to increase income and customer confidence. Some MSMEs strive to improve information and technology to provide a satisfying service to their customers. The excellent service includes a fast and accurate service. Undoubtedly, every customer expects fast and precise service. Hence, all MSMEs are racing to create innovation that can enhance the quality of their service.

When preparing an effective marketing strategy, corporations must consider their competitors and customers. Establishing a mutual relationship requires a better means of satisfying customer's needs than the competitors. The MSMEs should always analyze their competitors and develop marketing strategies that effectively give the company a good position compared to the competitors and provide a competitive advantage as strong as possible.

\section{Literature Review}

2.1 Customer Loyalty

Several indicators are used to measure the variables of customer loyalty, such as:

1. Repeated transactions refer to the frequency of the bank's customer in doing transactions through the bank services.

2. Recommending the product to other customers, when the customers are satisfied with the quality of products and services of a financial institution, it is very likely that they will recommend the institution products/services to other people.

3. Using other services, because the customers satisfy with certain products or services, they will have an urge to try other services offered by the institution.

4. Do not move to other banks; consumers who have the convenience and trust in a bank will not be easily persuaded by offers from competitors even if the products or services have some similarities.

\subsection{Customer Satisfaction}

Satisfaction comes from the Latin "satis" (meaning good enough, adequate) and "facio" (doing or making). In simple terms, satisfaction can be defined as an effort to fulfill something or make something passable. However, viewed from consumer behavior, the term consumer satisfaction then becomes something complex (Suwarsito \& Aliya, 2020).

Customer satisfaction is the accumulation of various intense affective responses and the evaluation that products or services of the companies fulfill a certain degree of satisfaction related to consumption. It includes the level of under fulfillment and over fulfillment expressed in Fandy Tjiptono and Gregorius Chandra's book. According to Schiffman and Kanuk, customer satisfaction is the individual's perception of the product or service's performance concerning his or her expectation.

Kotler defines customer satisfaction as comparing the customer's expectation and what they obtain (perceived quality). Customer satisfaction is usually affected by value perception, which means a comprehensive evaluation of the usefulness of a product based on customer perceptions towards several benefits that they receive compared to the sacrifices made. Besides, customer 
confidence is believed to serve as an element that maintains a relationship in the long run. When customer satisfaction and trust can be achieved, long-term customer loyalty will be formed.

Companies should consider five factors to decide customer satisfaction, including

1. Product quality means customers will feel satisfied if they know that the product they use is of good quality.

2. Service quality, customers will feel satisfied when they receive good services as expected.

3. Emotion, customers will be proud and confident that other people are amazed when using certain branded products. The satisfaction does not come from the quality of the product. Instead, it comes from the social or self-esteem that makes the customers feel satisfied with the brand.

4. Price, products with similar quality but lower prices will give an advantage in the customer's eyes.

5. Cost and accessibility, the customers do not need to pay the additional fee or spend time to obtain the products or services.

\subsection{Service Quality}

Service quality is one of the conditions for the survival of a company or institution. The high quality of services provided is reflected in the satisfaction aspects of service users. Today, the concept of service quality has been considered crucial and universal to become decisive factors towards the institution's success.

According to Kotler, quality should begin with the customer's needs and end with the customer's perception. It means that the image of good quality is not based on the service provider's point of view or perception, but the customer's point of view or perception. Parasuraman, cited in Tjiptono, expresses five dimensions of quality products or services, covering:

\section{Tangibles}

This aspect is physical evidence that must be possed by bank employees, such as building, office equipment, employee's attractiveness, communication facilities, and other physical facilities. The customers will directly see the physical evidence. Therefore, the physical evidence should appear exciting and modern. In this case, the strategy for determining the room's location, layout, and design determines the characteristics of a bank. Customer convenience in the bank office deserves attention.

2. Responsiveness

This dimension denotes the desire and willingness of employees in providing services to consumers. Thus, the management of the MSMEs should motivate all employees to provide services to consumers equally. It will be better if the motivation is given in the form of incentives based on the performance of the employees. All employees from the lowest to the highest levels must respond to the customer's request.

3. Assurance

This dimension assures all employees have knowledge, competencies, politeness, and trustworthy attitudes or behavior. It is crucial to convince the customers the quality of the batik that they use is correct and on target. The employees should understand the specifications of all products to receive a proper explanation that leads them to become loyal customers.

4. Reliability

This aspect refers to the ability of MSMEs to provide the promised service quickly, accurately, and satisfy their customers. In so doing, every employee should be sent to attend training and education to improve their competencies. With the advancement of today's technology, speed, accessibility, and accuracy of the customer's need are highly demanded. 


\section{Empathy}

This aspect denotes the ability to provide easiness and to establish a relationship with the customers effectively. It also includes the ability to understand each customer's needs quickly, correctly, and accurately. In this case, work procedure could be linked to the level of service to the customers.

\subsection{Competitive Advantage}

Competitive advantage has been used widely as the central concept of a strategy. Every company attempts to identify and create a competitive advantage. Porter advocates competitive advantage yet suggests that the competitive advantage should not be meant only by practical innovation. It is gained to be different, not to be better

Competitive advantage grows fundamentally by giving merit from the MSMEs to create more customers with affordable cost according to MSMEs abilities which indeed have strengths and weaknesses compared to the competitors. There are two basic types of competitive advantage, namely low cost and differentiation. By taking this strategy followed the ability to maintain and develop the plan, a company will gain its position in the market. The company should find the best method to exploit the characteristics of the company and its uniqueness. The company should also support the competitive advantage, although this idea is against Porter's views that echo the possibilities of creating competitive advantage from practical operational activities.

Competitive advantage is the ability of a company to provide added value (more than the competitors) deemed necessary by the customers. The competitive advantage grows from values or benefits created by the company to its customers. These values are more than the cost that should be paid to make them. The advantage can use several ways that enable the company to select and implement a general strategy to achieve and maintain the competitive advantage. Five competitive factors that determine a company's ability include newcomers, suppliers, customers, substitute products, and competition among existing companies.

Barney points out that competitive advantage is a strategy of creating value for corporations that their potential competitors do not yet apply. The system of competitive advantage should have the following characteristics: rare (barely used), valuable (added value), and not inimitable (cannot be copied) based on the available resources. In short, a company's competitive advantage should be compared to other companies and does not have a specific standard.

Ferdinand explains that competitive advantage can be taken from the ability of the company to utilize various resources and capabilities as its strategic assets. Managing this strategic asset will determine the company's competitive advantage that may create a different position compared to its competitors. This idea is confirmed by Barney, who studies advantage sources in a business competition.

In his research, Keltner highlights the importance of a bank to build a good relationship, especially a long-term one. As the competition paradigm shifts from short transactional relationships to longterm relationships, retaining and maintaining relationships with customers plays a pivotal role in winning the competition. The long-term relationship in this context is exemplified by customer loyalty, which can improve the company's competitive advantage.

Some factors are used to explain variables of competitive advantage, as explained by Bharadwaj et al. and Keltner. The factors above involve:

1. Competitive advantage is the customer's perception of the ability of the company to compete with other banks in the long run. 
2. Network breadth refers to the customer's perception that the bank will keep expanding its network as the customer increases to widen the service coverage.

3. Increasing sources of the fund are the customer's perception that the third-party sources of the fund will increase as the number of customers increases.

4. The technological advantage is the strength in technology to support customer's transactions.

Bharadwaj's study indicates that customer loyalty is one source to build a competitive advantage for service-based companies. Customer loyalty will lead the company to have a definite source of income (from loyal customers) to make the company able to compete in the long term. It is understandable since customer loyalty plays an essential role amid the increasing business competition. Loyal customers are difficult to persuade to move to another company. A study by Smith and Wright on the personal computer industry also reveals that high customer loyalty will produce a competitive advantage.

\section{Research Method}

This research used a quantitative approach. As the name suggests, this sort of research uses numerical data and statistical data analysis. The research method referred to causal research, which denoted a causal relationship. The researcher used path analysis to analyse the data because there was affecting mediation between independent and dependent variables. Three variables were used in this research, namely:

a. The independent variable, a variable that causes the dependent variable to occur/affect. In this context, the independent variables were Customer Satisfaction and Service Quality ( $\mathrm{X}_{1}$ and $\mathrm{X}_{2}$ ).

b. The dependent variable, a variable whose value is affected by the independent variable. In this research, the dependent variable is referred to as Competitive Advantage (Y).

c. Intervening variable, a variable that acts as a mediator between independent and dependent variables. In this research, the intervening variable was customer loyalty $(Z)$. Customer loyalty served as a mediator to identify the relationship or effect of customer satisfaction and service quality $\left(\mathrm{X}_{1}\right.$ and $\left.\mathrm{X}_{2}\right)$ towards competitive advantage $(\mathrm{Y})$.

Figure 1.1 The Design of Operational Variables

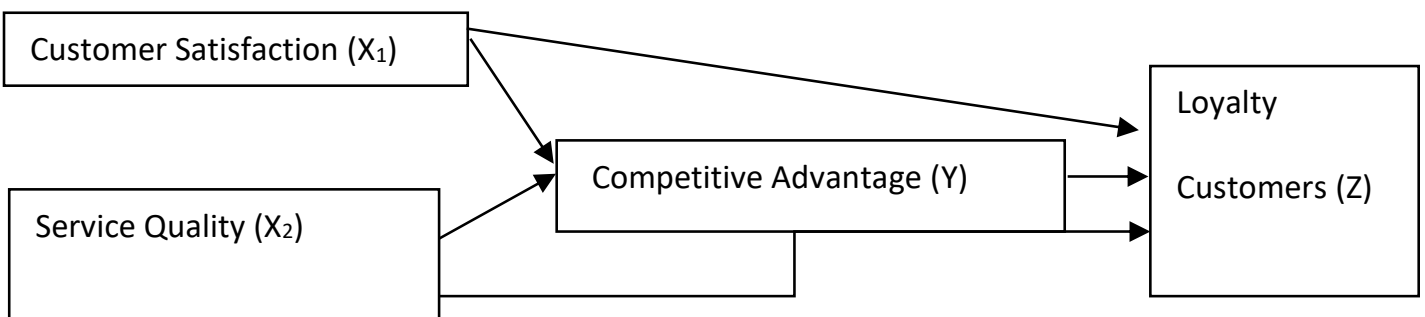

Source: Adapted by author, 2021

\section{Result and Discussions}

Based on the research findings, customer satisfaction $\left(\mathrm{X}_{1}\right)$ had a significant direct effect on competitive advantage $(\mathrm{Y})$, with a significance value of $0.004<0.05$. Thus, it can be concluded that there was a significant direct effect of customer satisfaction $\left(\mathrm{X}_{1}\right)$ on competitive advantage 
(Y), in which the R Square reached 0.826 . The summary table showed that customer satisfaction significantly affected competitive advantage by $82.6 \%$. Meanwhile, the rest $(17.4 \%)$ referred to other factors not included in this research. It means that customer satisfaction had a significant positive effect on competitive advantage in the Sentra Batik Pamekasan. Based on the findings, customer satisfaction $\left(\mathrm{X}_{1}\right)$ had a significant direct impact on customer loyalty $(\mathrm{Z})$, with a significance value of $0.499<0.05$. Thus, it can be concluded that there was a significant direct effect of customer satisfaction $\left(\mathrm{X}_{1}\right)$ on customer loyalty $(\mathrm{Z})$, in which the R Square reached 0.616. The summary table showed that customer satisfaction significantly affected customer loyalty by $61.6 \% \%$. Meanwhile, the rest (38.4\%) referred to other factors not included in this research. It means that customer satisfaction has a significant positive effect on customer loyalty in the Sentra Batik Pamekasan.

The findings also reported that service quality $\left(\mathrm{X}_{2}\right)$ had a significant direct effect on competitive advantage $(Y)$, with a significance value of $0.000<0.05$. Thus, it can be concluded that there was a significant direct effect of service quality $\left(\mathrm{X}_{2}\right)$ on competitive advantage $(\mathrm{Y})$, in which the $\mathrm{R}$ Square reached 0.826 . The summary table showed that the service quality significantly affected competitive advantage by $82.6 \%$. Meanwhile, the rest $(17.4 \%)$ referred to other factors not included in this research. It means that service quality had a significant positive effect on competitive advantage in the Sentra Batik Pamekasan. Based on the findings, service quality $\left(\mathrm{X}_{2}\right)$ had a significant direct impact on customer loyalty $(Z)$, with a significance value of $0.062<0.05$. Thus, it can be concluded that there was a significant direct effect of service quality $\left(\mathrm{X}_{2}\right)$ on customer loyalty $(\mathrm{Z})$ in which the R Square reached 0.616 . The summary table showed that the service quality significantly affected customer loyalty by $61.6 \% \%$.

Meanwhile, the rest (38.4\%) referred to other factors not included in this research. It means that service quality has a significant positive effect on customer loyalty in the Sentra Batik Pamekasan. The findings also reported that competitive advantage $(\mathrm{Y})$ had a significant direct impact on customer loyalty $(\mathrm{Z})$, with a significance value of $0.028<0.05$. Thus, it can be concluded that there was a significant direct effect of competitive advantage (Y) on customer loyalty (Z), in which the R Square reached 0.616 . The summary table showed that competitive advantage significantly affected customer loyalty by $31.6 \%$. Meanwhile, the rest $(38.4 \%)$ referred to other factors not included in this research. It means that competitive advantage had a significant positive effect on customer loyalty in the Sentra Batik Pamekasan.

\section{Conclusion}

Based on the research discussion and findings on customer satisfaction, service quality, and competitive advantage towards customer loyalty in Sentra Batik Pamekasan, it can be concluded that:

1. Customer satisfaction $\left(\mathrm{X}_{1}\right)$ had a significant direct effect on competitive advantage $(\mathrm{Y})$, with a significance value of $0.004<0.05$. Thus, it can be concluded that there was a significant direct effect of customer satisfaction $\left(\mathrm{X}_{1}\right)$ on competitive advantage $(\mathrm{Y})$, in which the $\mathrm{R}$ Square reached 0.826 . The summary table showed that customer satisfaction significantly affected competitive advantage by $82.6 \%$. Meanwhile, the rest (17.4\%) referred to other factors not included in this research. It means that customer satisfaction had a significant positive effect on competitive advantage in the Sentra Batik Pamekasan.

2. Customer satisfaction $\left(\mathrm{X}_{1}\right)$ had a significant direct effect on customer loyalty $(\mathrm{Z})$, with a significance value of $0.499<0.05$. Thus, it can be concluded that there was a significant direct effect of customer satisfaction $\left(\mathrm{X}_{1}\right)$ on customer loyalty $(\mathrm{Z})$, in which the R Square reached 0.616 . The summary table showed that customer satisfaction significantly affected customer loyalty by $61.6 \% \%$. Meanwhile, the rest (38.4\%) referred to other factors not included in this 
research. It means that customer satisfaction has a significant positive effect on customer loyalty in the Sentra Batik Pamekasan.

3. Service quality $\left(\mathrm{X}_{2}\right)$ had a significant direct effect on competitive advantage $(\mathrm{Y})$, with a significance value of $0.000<0.05$. Thus, it can be concluded that there was a significant direct effect of service quality $\left(\mathrm{X}_{2}\right)$ on competitive advantage $(\mathrm{Y})$, in which the R Square reached 0.826 . The summary table showed that the service quality significantly affected competitive advantage by $82.6 \%$. Meanwhile, the rest $(17.4 \%)$ referred to other factors not included in this research. It means that service quality had a significant positive effect on competitive advantage in the Sentra Batik Pamekasan.

4. Service quality $\left(\mathrm{X}_{2}\right)$ had a significant direct effect on customer loyalty $(\mathrm{Z})$, with a significance value of $0.062<0.05$. Thus, it can be concluded that there was a significant direct effect of service quality $\left(\mathrm{X}_{2}\right)$ on customer loyalty $(\mathrm{Z})$, in which the $\mathrm{R}$ Square reached 0.616 . The summary table showed that the service quality significantly affected customer loyalty by $61.6 \% \%$. Meanwhile, the rest (38.4\%) referred to other factors not included in this research. It means that service quality has a significant positive effect on customer loyalty in the Sentra Batik Pamekasan

5. Competitive advantage ( $\mathrm{Y})$ had a significant direct effect on customer loyalty $(\mathrm{Z})$, with a significance value of $0.028<0.05$. Thus, it can be concluded that there was a significant direct effect of competitive advantage (Y) on customer loyalty (Z), in which the R Square reached 0.616 . The summary table showed that competitive advantage significantly affected customer loyalty by $31.6 \%$. Meanwhile, the rest (38.4\%) referred to other factors not included in this research. It means that competitive advantage had a significant positive effect on customer loyalty in the Sentra Batik Pamekasan.

\section{Reference}

Cahyani Dwi Putri, Tingkat Kepuasan Konsumen Terhadap Kualitas Layanan Perbankan Syariah di Yogyakarta, Jurnal Bisnis dan Manajemen, Volume 6 (2), Oktober 2016.

Danibrata Aulia, Pengaruh Strategi Bersaing Dengan Menggunakan Kualitas dan Kerelasian Pelanggan Terhadap Loyalitas Pelanggan Pada Industri Perbankan, Jurnal Bisnis dan Akuntansi, Vol.15, No.1, Juni 2013.

Dharmesta Swastha Basu, Hani Handoko, Manajemen Pemasaran dan Analisis Perilaku Konsumen, Yogyakarta: Penerbit Liberty, 1997.

Engel J.F, R.D Black Well, and P.W. Miniard, Marketing Management, Jakarta: Penerbit Erlangga, 2008.

Ghozali Imam, Aplikasi Analisisis Multivariate dengan Program SPSS Semarang: Badan Penerbit Universitas Diponegoro, 2001.

Hasan Iqbal, Analisis Data Penelitian Dengan Statistik, Jakarta: Bumi Aksara, 2010.

Hasan, Analisis Industri Perbankan Syariah, Jurnal Dinamika Ekonomi Pembangunan, Juli 2011, Volume 1, Nomor 1, Fakultas Ekonomi Universitas Wahid Hasyim Semarang.

Haryanto RestyAvita, "Strategi Promosi, Kualitas Produk, Kualitas Layanan Terhadap Kepuasan Pelanggan Pada Restoran MCDONALD'S Manado",ISSN 2303-1174, Jurnal EMBA Vol. 1 No.4 Desember 2013.

HayatiNur, Fatmasaris Sukesti, Peningkatan Loyalitas Konsumen Bank Syariah Melalui Peningkatan Kualitas Layanan dan Kepuasan Dengan Variabel Religiusitas Sebagai Variabel Moderating, Jurnal Economica, Volume VII/Edisi 2/Oktober 2016.

Huda Nurul, Mohammad Heykal, Lembaga Keuangan Islam : Tinjauan Teoritis dan Praktis, Jakarta: KENCANA PRENADA MEDIA GROUP, 2010.

Kotler Philip, Gary Amstrong, Prinsip-Prinsip Pemasaran, Jakarta : Erlangga, 2004.

Kotler Philip, Kevin Lane Keller, Marketing Management, Jakarta: Penerbit Erlangga, 2008. 
Kuncoro Mudrajad, Metode Kuantitatif; Teori dan Aplikasi untuk Bisnis \& Ekonomi. Edisi Keempat Yogyakarta: Unit Penerbit dan Percetakan Sekolah Tinggi Ilmu Manajemen YKPN, 2011.

Laksana Fajar, Manajemen Pemasaran; Pendekatan Praktis, Yogyakarta: Graha Ilmu, 2008.

Lupiyoadi Rambat, Manajemen Pemasaran Jasa: Teori dan Praktik, Jakarta: PT. Salemba Emban Patria, 2001.

Martono Nanang, Manajemen Penelitian Kuantitatif, Jakarta: PT.Raja Grafindo Persada, 2011.

Marwanto Aris, Marketing sukses, Yogyakarta: PT. Buku Kita 2015.

Nuryana Fatati, Statistik Bisnis Jilid I, Surabaya: Pena Salsabila, 2013.

Pritandhari Meyta, Analisis Faktor-Faktor yang Mempengaruhi Loyalitas Pelanggan dan Dampaknya Terhadap Keunggulan Bersaing (studi Pada BMT AMANAH UMMAH SUKOHARJO) jurnal Pendidikan Ekonomi UM Metro Vol.3 No.1 2015.

Ridwan, Sunarto, Pengantar Statistik Untuk Penelitian, Bandung: Alfabeta, 2009.

Rosda Yusmi Aulia, Analisis Pengaruh Kepercayaan, Komunikasi, Komitmen, dan Penanganan Keluhan Terhadap Loyalitas Konsumen Di PT Bank Negara Indonesia Syariah Kantor Cabang Sudirman Pekanbaru, Skripsi UIN SUSKA RIAU, RIAU, 2015.

Semuel Hatane, Nadya Wijaya, Service Quality, Perceive Value, Satisfaction, Trust Dan Loyalty, Pada PT. Kereta Api Indonesia Menurut Penilaian Pelanggan Surabaya, Jurnal Manajemen Pemasaran, VOL.4, NO. 1, April 2009.

Setiawan Rachmawati Yenny, Pengaruh Kepuasan Pelayanan Terhadap Loyalitas Konsumen dan Strategi Untuk Mencapai Keunggulan Bersaing Pada Bank Permata Cabang Yogyakarta, Skripsi Universitas Diponegoro Semarang, 2006.

Simamora Bilson, Riset Pemasaran, Falsafah, Teori, dan Aplikasi, Jakarta: PT. Gramedia Pustaka Utama, 2004.

Sondakh Conny, Kualitas Layanan, Citra Merek dan pengaruhnya terhadap Kepuasan dan Loyalitas Konsumen Tabungan (Studi Pada Konsumen Taplus BNI Cabang Manad0), Jurnal Riset Bisnis dan Manajemen vol.3, No.1,2014, diakses pada, 24 November 2018.

Subanti Sri, Arif Rahman Hakim, Ekonometri, Yogyakarta: Graha Ilmu, 2014.

Sugiyono, Metode Penelitian Bisnis, Bandung: Alfabeta, 2012.

Suryaningtyas Dewi, nuruddin Harahab, Harsuko Riniwati, Analisis Kualitas Pelayanan Karyawan Terhadap Kepuasan Pelanggan (Nelayan), Di UPTD Pangkalan Pendaratan Ikan (PPI) POPOH, Desa Besole Kecamatan Besuki, Tulungangung, Jawa Timur, Jurnal ECSOFIM Vol.1 No.1, 2013.

Siregar Syofian, Statistika Deskriptif untuk Penelitian, Jakarta: PT Raja Grafindo Persada, 2012. Suharsaputra Uhar, Metodologi Penelitian Kuantitatif, Kualitatif, dan Tindakan, Bandung: PT Refika Aditama, 2012.

Suharyadi, Purwanto S.K, STATISTIKA: Untuk Ekonomi dan Keuangan Modern, Jakarta: Salemba Empat, 2011.

Sunarto, Analisis Faktor-Faktor Yang Mempengaruhi Loyalitas Pelanggan dan Dampaknya Terhadap Keunggulan Bersaing (Studi Pada Tabungan BRITAMA BRI KANCA KENDAL), Tesis Universitas Diponegoro, Semarang, 2006.

Supriyanto Sani Ahmad, Masyhur Mahfud, Metodologi Riset Manajemen Sumber Daya Manusia , Malang: UIN Maliki Press, 2010.

Suwarsito, S., \& Aliya, S. (2020). Kualitas Layanan dan Kepuasan Serta Pengaruhnya Terhadap Loyalitas Pelanggan. Jurnal Ilmiah Bina Manajemen, 3(1), 27-35. https://doi.org/10.33557/jibm.v3i1.826

Tahuman Zainuddin, Analisis Faktor-Faktor Yang Mempengaruhi Loyalitas Pelanggan Serta Dampaknya Terhadap Keunggulan Bersaing, Jurnal Riset Bisnis dan Manajemen Vol.4, No.3, Edisi Khusus Pemasaran \& Keuangan 2016. 


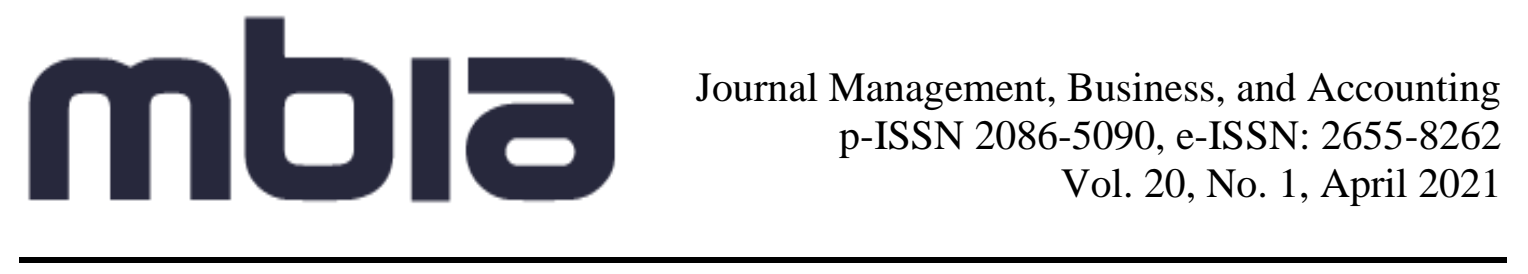

Tim Penyusunan Pedoman Karya Ilmiah, Pedoman Penulisan Karya Ilmiah, Pamekasan: STAIN Pamekasan, 2015.

\section{Copyright Disclaimer}

Copyright for this article is retained by the authors, with first publication rights granted to the journal. 